\title{
Meta Analysis: The Relationship Ofknowledge And Family Support With The Behavior Of Mother-Toddler In Using Posyandu
}

\author{
Yeni Wahyu Ulfarini ${ }^{1}$, Husaini ${ }^{1}$, Syamsul Arifin ${ }^{2}$, Roselina Panghiyangani ${ }^{2}$, Lenie Marlinae ${ }^{3}$ \\ ${ }^{I}$ Master of Public Health Study Program, Faculty of Medicine, Lambung Mangkurat University \\ ${ }^{2}$ Faculty of Medicine, Lambung Mangkurat University \\ Email: ulfa.ulfe@gmail.com
}

DOI: 10.29322/IJSRP.11.07.2021.p11525

http://dx.doi.org/10.29322/IJSRP.11.07.2021.p11525

\begin{abstract}
Background:One indication of the use of health services by the community is the activeness of the arrival of the community to the health service center, in this case specifically the utilization of posyandu services, namely the activity of parents bringing their children to the posyandu. Factors that influence the behavior of mothers under five in the use of posyandu are family knowledge and support. Based on preliminary studies in several journals, there are differences in the results of research on the variables of knowledge and family support with the behavior of mothers under five in the use of posyandu. Destination:Analyzing the greater relationship between knowledge and family support with the behavior of mothers under five in the use of posyandu. Method: Meta analysis with searches on the Google Scholar database. After going through the identification and selection stages, 11 articles were included in the meta-analysis. Pooled Odds Ratio (pOR) was calculated using a fixed effect model for data analysis according to heterogeneity test using Review Manager 5.4.1. Results: The pOR value for the knowledge variable is 2.91 (95\% CI 2.36-3.61) and for the family support variable 2.76 (95\% CI 2.18-3.51) Conclusion: the knowledge variable has a higher effect greater than the family support variable.
\end{abstract}

Keywords : Knowledge, Family Support, Mother's Behavior in Utilizing Posyandu.

\section{INTRODUCTION}

$\mathrm{T}$ The health development target to be achieved in 2025 is to increase the degree of public health as indicated by an increase in life expectancy, a decrease in infant mortality, a decrease in maternal mortality, and a decrease in the prevalence of malnutrition in children under five (Sumini, 2014). Regarding community empowerment, Posyandu is one of the Community-Based Health Efforts that is managed and organized from, by, for and with the community to empower and provide convenience to the community to obtain basic health services for mothers, infants and toddlers where this program can be implemented at the hamlet hall, the village hall, as well as other places that are easily accessible by the community (Yuniyanti \& Masini, 2016).
Growth in toddlers can be monitored by weighing the child's weight every month. Monitoring the growth of children under five that is carried out every month shows that the percentage of children aged 6-59 months who have never been weighed in the last six months tends to increase from 25.5\% (2007), 23.8\% (2010) to 34.3\% (2013) (Ministry of Health RI, 2013).

One indication of the use of health services by the community is the active arrival of the community to the service center, in this case specific to the use of posyandu services, namely the activeness of children coming to the posyandu or the activity of parents bringing their children to the posyandu which can be seen from the comparison between the number of children weighed compared to the number of children. all toddlers in the area or D/S (Kemenkes, 2011).

According to data from the Health Profile of the Republic of Indonesia (2019), the number of posyandu in Indonesia has increased, where in 2018 there were 283,370 posyandu to 296,777 posyandu in 2019. A total of 188,855 posyandu or around $63.6 \%$ of them were active posyandu. Active posyandu are posyandu that are able to carry out their main activities regularly every month $(\mathrm{MCH}$ : pregnant women, postpartum mothers, infants, toddlers, family planning, immunization, nutrition, prevention, and control of diarrhea) with a minimum coverage of $50 \%$ each and perform additional activities (Directorate General of Public Health, Ministry of Health RI, 2020).

Many factors are associated with mother visits in bringing toddlers to the posyandu. According to WHO in Notoatmodjo (2007), there are four main reasons that cause a person to behave, namely: 1) Thoughts and feelings, 2) Important people as references, 3) Resources, and 4) Culture. In the factor of thinking and feeling there is knowledge. This knowledge is obtained from one's own experience or the experience of others. According to the results of research conducted by Harahap SA et al (2020) stated that there was a significant relationship between Mother's Knowledge and the activeness of Mother's visits to the Sialagundi Posyandu. From the results of statistical tests performed using the chi-square test, it was obtained that the value of $\mathrm{p}=0.006(\mathrm{p}<)$ where $0.006<0.05$. It is also known that the PR value is 5.909 , so it can be assumed that mothers 
ISSN 2250-3153

with good knowledge have a 5.909 times more chance of being active in visiting the Sialagundi Posyandu.

This is in line with the research of Setiati NW et.al (2019) which stated that there was a significant relationship between the level of knowledge of mothers about posyandu with toddlers and posyandu visits. From the results of statistical tests obtained $p$ value $=0.002(\mathrm{p}<)$ where $0.002<0.05$. It is also known that the pOR value is 12.009 .

However, the research above is not in line with the research of Ifroh RH et al (2018) which stated that there was no relationship between knowledge and mother's behavior in the use of posyandu with a statistical test $p$ value $=0.728(p>0.05)$. Low or high knowledge scores did not have any effect on visits to the Tarap posyandu.

Another factor that influences health behavior, in this case the visits of toddlers to the posyandu, is family support. Snehandu B Karr stated that one of the factors related to the behavior of obtaining health action or not is social support, one of which is from the family.

The results of Amaliah E et.al's research (2019) showed that there was a relationship between family support and Posyandu visits by mothers of toddlers in Tanjung Pauh Village, Ibuh Health Center Work Area, Payakumbuh City with a $\mathrm{p}$ value $=$ 0.001 , and a pOR value of 6.85 . This means that mothers of toddlers who have poor family support are 6,853 times more likely not to visit Posyandu with toddlers compared to those who have good family support. This is in line with the research of Fauziah et.al (2014) which showed that the Chi Square statistical test results obtained a value of $p=0.010(p=0.05)$ so that it can be concluded that there is a relationship between family support and maternal visits to the posyandu. However, this is not in line with the research of Ifroh RH et al (2018) which states that there is no relationship between family support and maternal behavior in the use of posyandu with statistical results showing $\mathrm{p}$ value $=$ $0.389(\mathrm{p}>0.05)$.

Based on the results of the previous studies above, it can be seen that there are differences in the results of research on each variable, there are studies which state that there is a relationship and there are also studies that state that they are not related. This shows that there are differences in the results of research on the variables of mother's knowledge and family support on the behavior of mothers under five in the use of posyandu. Therefore, it is considered important to conduct a meta-analysis study by combining several research results regarding the relationship between mother's knowledge and family support on the behavior of mothers under five in the use of posyandu in order to determine the tendency of the relationship between these variables. Research with meta-analysis is a technique used to summarize the findings of two or more studies with the aim of combining, review and summarize previous research. In addition, by using meta-analysis, various questions can be investigated based on data that has been found from the results of previous studies that have been published and one of the requirements needed in conducting a meta-analysis is an assessment of the results of similar research (Sriawan et al., 2015). One of the advantages of meta-analysis is that a new study with a large number of subjects can be obtained so that more definitive conclusions can be drawn (Anwar R., 2005).

\section{RESEARCH METHOD}

This type of research is a meta-analysis study where the researcher uses several similar research articles to be combined so that new data is obtained and quantitative testing is carried out.In this meta-analysis, an observational study was conducted to get estimate effect size, namely the strength of the relationship or the magnitude of the difference between variables (Borenstein, 2009).

The strategy for searching for published articles for the last 5 years (2016-2021) is done by opening an electronic database, namely Googlescholar, using both Indonesian and English. The article search results using a flow chart according to the 2009 PRISMA-P checklist instrument protocol eliminates articles that do not match the search topic with the criteria of identification, article filtering, article eligibility, and the last step is to download the relevant article, using the following keywords:

1. Factors related to the behavior of mothers under five in the use of posyandu, mother's knowledge, family support.

2. Factors related to the behavior of mothers under five in the use of posyandu, Mother's knowledge, family support. 


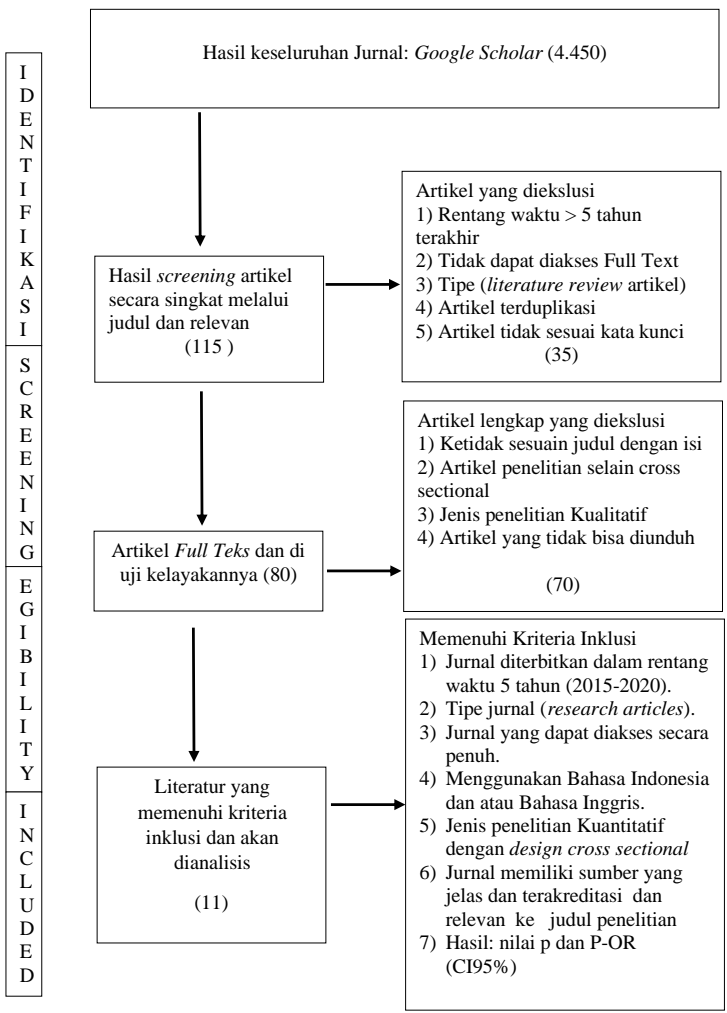

Sumber: Diagram PRISMA (Pangesti \& Kusumawati, 2019

Gambar 3.1 Diagram/ Bagan PRISMA (Preferred Reporting Items for

Systematic Reviews and Meta-analyses)

The quality of the data was analyzed using the table Duffy's Research Appraisal Checklist Approach according to the inclusion criteria that have been set, after that identification of research questions using SPIDER(Sample, Phenomenon of Interest, Design, Evaluation, Research type) with the following explanation:

1. S for Samples.

The sample in this study is a journal related to the behavior of mothers under five in the use of posyandu.

2. PI for Phenomenon of Interest.

An interesting phenomenon in this study is how the tendency of the relationship between knowledge and family support with the behavior of mothers under five in the use of posyandu.

3. D for Design.

Observational research design with cross sectional method
4. E for Evaluation.

The relationship between knowledge and family support factors with the behavior of mothers under five in the use of posyandu.

5. $\mathrm{R}$ for Research type.

This type of quantitative research.

After that, the statistical data analysis was continued using the Revman 5.4.1 application.

\section{FINDINGS}

Results of data synthesis

The results of data synthesis using SPIDER obtained data from the two independent variables, namely sample size (n), significant value of $\mathrm{p}$ value, odds ratio, Confidence Interval $(95 \% \mathrm{CI})$. The description of the data can be seen in tables 1 and 2 below:

Table 1. Research Characteristics of the Relationship between Mother's Knowledge and Behavior of Mothers toddler in the use of Posyandu

\begin{tabular}{ccccccc}
\hline No & Researcher & Year & $\begin{array}{c}\text { N } \\
\text { (Sample) }\end{array}$ & p value & OR & 95\% CI \\
\hline 1. & Djamil A & 2017 & 198 & 0.027 & 2.26 & $(1,187-4,302)$ \\
\hline 2. & Gumayesty Y & 2017 & 63 & 0.029 & 3,682 & $(1,271-10,668)$ \\
\hline 3. & Idaningsih A & 2016 & 110 & 0.033 & 2,764 & $(1,170-6,526)$ \\
\hline 4. & Nurdin et.al & 2019 & 85 & 0.021 & 3,098 & $(1,270-7,557)$ \\
\hline 5. & Reihana et.al & 2016 & 407 & 0.000 & 4,614 & $(3.249-6.551)$ \\
\hline 6. & Sari CK & 2021 & 55 & 0.045 & 3,972 & $(1,031-15,299)$ \\
\hline 7. & Yanti M et.al & 2018 & 381 & 0.008 & 1,857 & $(1.175-2.934)$ \\
\hline
\end{tabular}

This publication is licensed under Creative Commons Attribution CC BY. 


\begin{tabular}{ccccccc}
\hline 8. & Utami RB et al & 2016 & 101 & 0.143 & 2.17 & $(0.76-6.16)$ \\
\hline 9. & Rahmawati et al & 2019 & 106 & 0.435 & 1,581 & $(0.745-3.352)$ \\
\hline Total Sample & & $\mathbf{1 , 5 0 6}$ & & & \\
\hline Average & & & $\mathbf{0 . 0 2 3}$ & $\mathbf{3 . 1 8}$ & \\
\hline
\end{tabular}

Table 2. Research characteristics of the relationship between family support and the behavior of mothers toddler in the use of posyandu

\begin{tabular}{lllllll}
\hline No & Researcher & Year & $\begin{array}{l}\text { N } \\
\text { (Sample) }\end{array}$ & p value & OR & 95\% CI \\
\hline 1. & Djamil A & 2017 & 198 & 0.010 & 3,684 & $(1,446-9,387)$ \\
\hline 2. & Ernawati et.al & 2018 & 200 & 0.001 & 7.51 & $(3.40-16.58)$ \\
\hline 3. & Idaningsih A & 2019 & 85 & 0.006 & 3,405 & $(1,482-7,825)$ \\
\hline $\mathbf{4 .}$ & Rahmawati et.al & 2019 & 106 & 0.001 & 2,908 & $(1,555-5.439)$ \\
\hline $\mathbf{5 .}$ & Reihana et.al & 2016 & 407 & 0.003 & 2,542 & $(1,381-4,680)$ \\
\hline $\mathbf{6 .}$ & Utami RB et.al & 2016 & 101 & 0.03 & 2.64 & $(1.09-6.38)$ \\
\hline $\mathbf{7 .}$ & Yanti M et.al & 2018 & 381 & 0.0001 & 2,224 & $(1.49-3.33)$ \\
\hline $\mathbf{8 .}$ & Widiyanto J et al & 2020 & 255 & 0.945 & 0.959 & $(0.289-3.187)$ \\
\hline & Total Sample & & $\mathbf{1 , 7 3 3}$ & & & \\
\hline & Average & & $\mathbf{0 . 1 2 4}$ & $\mathbf{3 , 2 3 4}$ & \\
\hline
\end{tabular}

Based on the results of the analysis using SPIDER, it is known that the number of samples in the knowledge variable is 1,506 samples and the family support variable is 1,733 samples, the average sample is taken using random sampling technique. The average $\mathrm{p}$ value of the knowledge variable is $0.023(\mathrm{p}<0.05)$, which means that there is a relationship between knowledge and the behavior of mothers of children under five in the use of posyandu. Meanwhile, in the family support variable, the $p$ value is $0.124(\mathrm{p}>0.05)$, which means that there is no relationship between support and the behavior of mothers under five in the use of posyandu. For the average OR value on the knowledge variable, the result is 3.18 , which means that mothers of toddlers who have high knowledge can improve the behavior of mothers of toddlers in the use of posyandu by 3, 18 times compared to mothers of toddlers who have low knowledge.

Based on the results of the analysis using SPIDER, it is known that with good knowledge possessed by mothers of toddlers about posyandu, there is a tendency to influence the formation of behavior, namely mothers of toddlers can actively participate in posyandu. If the behavior is not based on knowledge, it will be difficult to maintain its sustainability. Knowledge is very important to change and shape one's behavior, with high

a. Knowledge Variable

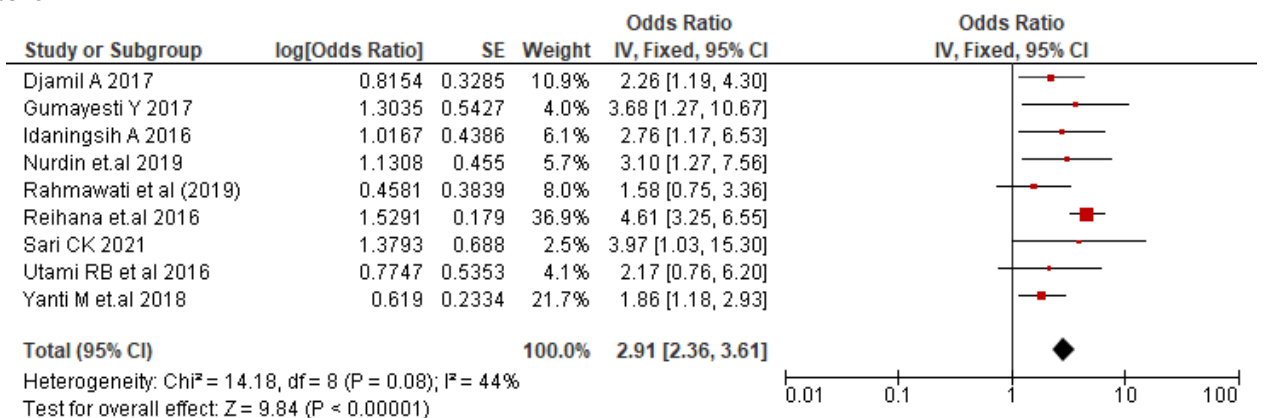

\footnotetext{
Keterangan :

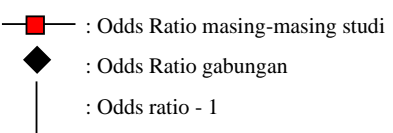

This publication is licensed under Creative Commons Attribution CC BY.

knowledge a person will quickly adopt new behaviors that are good for himself and others. According to the researcher's assumption, the respondents increased knowledge by providing counseling about posyandu and providing brochures to add information to mothers of toddlers about posyandu.

Based on research by Reihanah et al., (2016) states that every woman, both happy and unhappy when she is pregnant and has children, must be overcome by a mixture of feelings, namely a feeling of strength and courage to endure trials and feelings of weakness, fear, horror, anxiety especially in child-rearing time. In these conditions the husband can be an important source of strength, calm and encouragement for the mother. In this study, most of the research subjects had good family support. This shows that some people already know that providing good support to mothers with toddlers will increase their motivation to visit posyandu. Mothers who have good family support are more likely to visit posyandu with greater intensity than mothers who do not receive family support.

\section{Results of Data Analysis and Interpretation}

The results of data analysis using the Revman 5.4.1 application can be seen in the image below: 
Picture 1.Forest Plot a research study on the relationship between mother's knowledge and the behavior of mothers under five in the use of posyandu

Test for heterogeneity in 9 combined studies on the relationship between knowledge and behavior of mothers of children under five in the use of Integrated Healthcare Centerthe results obtained $\mathrm{p}$ value $=0.08$ and $\mathrm{I} 2=44 \%$, meaning that the level of heterogeneity is moderate. Then the Fixed Effect Model is used to measure the magnitude of the combined effect of the data in the data input model in the Revman 5.4.1 application.

The combined test results showed $p$ value $=0.00001$. Statistically, the combined effect is significant if the $\mathrm{p}$ value <
0.05 and this means that the null hypothesis is rejected, in other words, there is a relationship between knowledge and behavior of mothers under five in the use of posyandu. The data on the forest plot shows thatPooled value The odds ratio is 2.91 with a $95 \%$ confidence interval $(95 \% \mathrm{CI}=2.36-3.61)$, so it can be concluded that mothers who have a high level of knowledge tend to visit the posyandu 2.91 times compared to mothers who have a high level of knowledge. low knowledge.

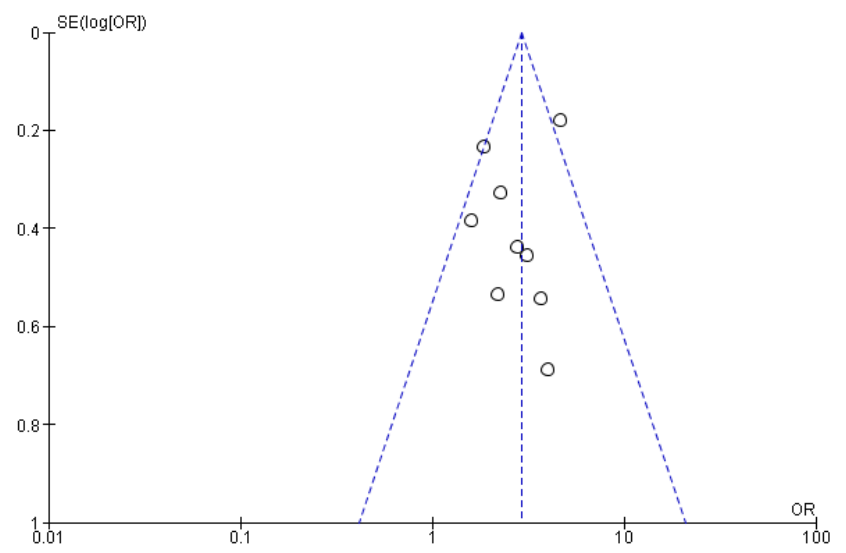

Figure 2. Funnel plot of the relationship of knowledge with the behavior of mothers of toddlers in the use ofIntegrated Healthcare Center

Figure 2 is resultfunnel plot from the results of the meta-analysis of the relationship between mother's knowledge and visits by mothers of toddlers to the posyandu, it can be seen in the picture above that there is publication bias because it is marked by the asymmetric distribution of plots on the right and left of the vertical line, the number of plots on the right side is 4 plots and the left side is 3 plot, and there are plots that touch the vertical line. Plots above the curve indicate that the study has a high ES while studies with plots below the curve indicate that the study has a low ES and plots that touch the vertical line indicate that the study is biased in the meta-analysis.

The effect size value for each study is shown in the SE column in the Forest plot. The calculated effect size for the combined effect size of research studies on the relationship between knowledge and behavior of mothers under five in the use of posyandu is done manually in the following table.

Table 4. The combined effect size of the relationship between knowledge and the behavior of mothers of children under five in the use of posyandu 


\begin{tabular}{|c|c|c|c|c|c|}
\hline No & Penelitian & $\mathbf{N}$ & ES & ES Max & ES Min \\
\hline 1. & Djamil A & \multirow{9}{*}{9} & 0,3285 & \multirow{9}{*}{0,688} & \multirow{9}{*}{0,179} \\
\hline & Gumayesty Y & & 0,5427 & & \\
\hline & Idaningsih A & & 0,4386 & & \\
\hline 4. & Nurdin et.al & & 0,455 & & \\
\hline 5. & Rahmawati et al & & 0,3839 & & \\
\hline & Reihana et.al & & 0,179 & & \\
\hline & Sari CK & & 0,688 & & \\
\hline & Utami RB et al & & 0,5353 & & \\
\hline & Yanti M et.al & & 0,2334 & & \\
\hline & ta-rata effect size & & 0,4205 & & \\
\hline
\end{tabular}

Based on table 4 above, it is known that the average effect size of the relationship between knowledge and behavior of mothers under five in the use of posyandu is 0.4205 . This shows that mother's knowledge has a moderate effect $(0.40<$ effect size 0.75$)$ on the behavior of mothers under five in the use of posyandu.

b. Family Support Variable

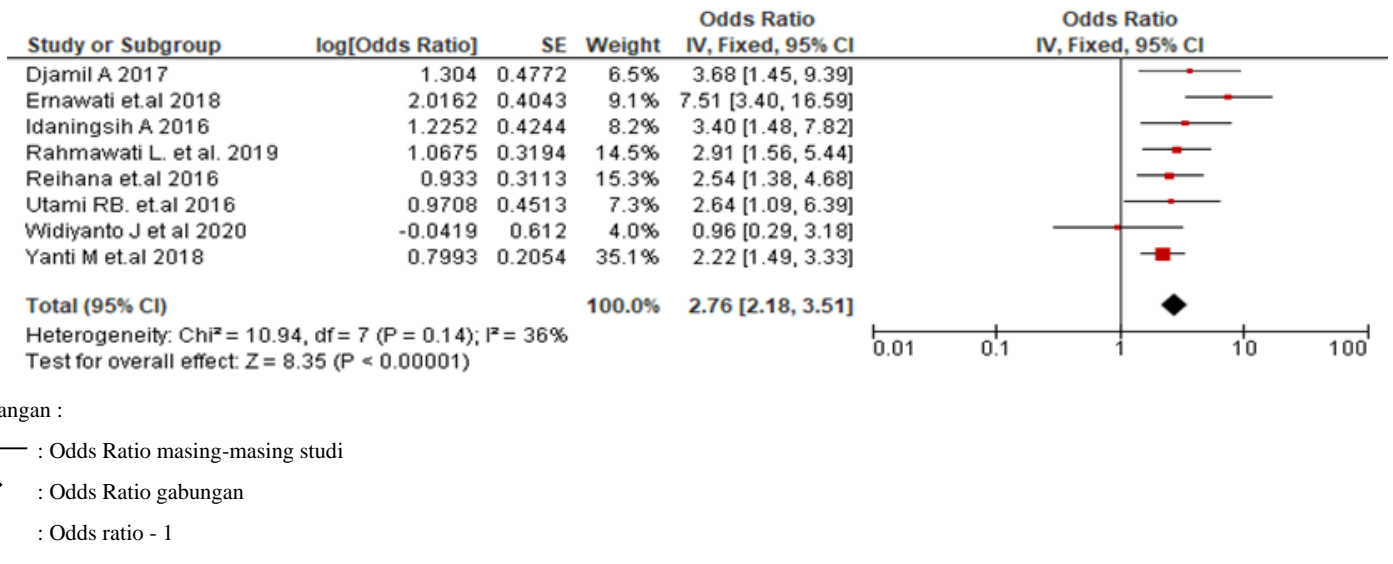

Figure 3.Forest Plot a research study on the relationship between family support and the behavior of mothers under five in the use of posyandu

Test for heterogeneity in 8 combined studies on the relationship between family support and the behavior of mothers under five in the use of Integrated Healthcare Centerthe results obtained $\mathrm{p}$ value $=0.14$ and $\mathrm{I} 2=36 \%$, meaning that the level of heterogeneity is moderate. Then the Fixed Effect Model is used to measure the magnitude of the combined effect of the data in the data input model in the Revman 5.4.1 application.

The combined test results showed $\mathrm{p}$ value $=0.00001$. Statistically, the combined effect is significant if the p value <
0.05 and this means that the null hypothesis is rejected, in other words, there is a relationship between family support and the behavior of mothers under five in the use of posyandu. The data on the forest plot shows thatPooled value The odds ratio is 2.76 with a $95 \%$ confidence interval $(95 \% \mathrm{CI}=2.18-3.51)$, so it can be concluded that mothers who receive family support tend to visit posyandu 2.76 times compared to mothers who do not. get family support. 


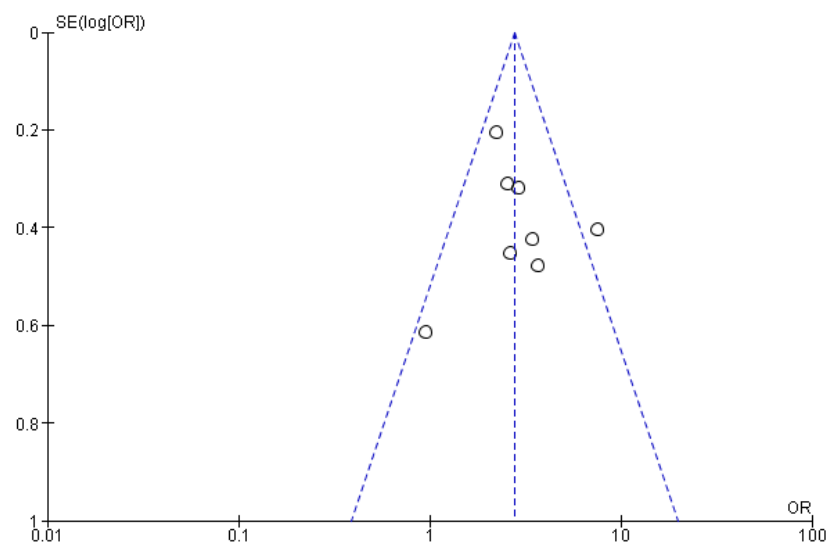

Figure 4 Funnel plotrelationship family support with the behavior of mothers under five in the use of posyandu

Result funnel plot from the results of the meta-analysis of the relationship between support and the behavior of mothers under five in the use of posyandu, it can be seen in the picture above that there is a publication bias because it is marked by the asymmetrical distribution of plots on the right and left of the vertical line, the number of plots on the right side is 2 plots and the left side is 3 plots, and there are 3 plots that touch the vertical line, as well as plots that are out of line. Plots above the curve indicate that the study has a high ES while studies with plots below the curve indicate that the study has a low ES and plots that touch the vertical line indicate that the study is biased in the meta-analysis.

The effect size value for each study is shown in the SE column in the Forest plot. The calculated effect size for the combined effect size of research studies on the relationship between family support and the behavior of mothers under five in the use of posyandu is done manually in the following table.

Table 5. Average Effect Besarsize Combined Relationship of Family Support with Mother Toddler's Visit to Poyandu

\begin{tabular}{|c|c|c|c|c|c|}
\hline No & Penelitian & $\mathbf{N}$ & ES & ES Max & ES Min \\
\hline 1. & Djamil A & \multirow{8}{*}{8} & 0,4772 & \multirow{8}{*}{0,612} & \multirow{8}{*}{0,2054} \\
\hline & Gumayesty Y & & 0,4043 & & \\
\hline 3. & Idaningsih A & & 0,4244 & & \\
\hline 4. & Nurdin et.al & & 0,3194 & & \\
\hline 5. & Reihana et.al & & 0,3113 & & \\
\hline & Sari CK & & 0,4513 & & \\
\hline & Widiyanto et al & & 0,612 & & \\
\hline & Yanti M et.al & & 0,2054 & & \\
\hline & ta-rata effect size & & 0.40 & & \\
\hline
\end{tabular}

Based on table 5 above, it is known that the average effect size of the relationship between family support and the behavior of mothers under five in the use of posyandu is 0.40 . That mattershow that mother's knowledge has a moderate effect
$(0.40<$ effect size 0.75$)$ on the behavior of mothers under five in the use of posyandu.

Meta analysis Factors Most Associated with the Behavior of Mothers under five in the use of Posyandu 
Table 6 Comparison of Research Results The Relationship between Research Variables and the Behavior of Mothers toddler in the use of Posyandu

\begin{tabular}{|c|c|c|c|}
\hline $\begin{array}{c}\text { Variabel } \\
\text { Penelitian }\end{array}$ & $\begin{array}{c}\text { Uji } \\
\text { Heterogenitas }\end{array}$ & Hasil Overall Effect & $\begin{array}{c}\text { Rerata Effect } \\
\text { Size }\end{array}$ \\
\hline $\begin{array}{l}\text { Pengetahuan } \\
\text { Ibu }\end{array}$ & $\begin{array}{l}\mathrm{p}=0,08 \\
\mathrm{I}^{2}=44 \% \\
\text { (heterogenitas } \\
\text { sedang) }\end{array}$ & $\begin{array}{l}\mathrm{p}=<0,00001 \\
\text { pOR }=2,91 \\
\text { CI } 95 \%=2,36-3,61\end{array}$ & 0,4205 \\
\hline $\begin{array}{l}\text { Dukungan } \\
\text { Keluarga }\end{array}$ & $\begin{array}{l}\mathrm{p}=0,14 \\
\mathrm{I}^{2}=36 \% \\
\text { (heterogenitas } \\
\text { sedang) }\end{array}$ & $\begin{array}{l}\mathrm{p}=<0,00001 \\
\mathrm{pOR}=2,76 \\
\text { CI } 95 \%=2,18-3,51\end{array}$ & 0,40 \\
\hline
\end{tabular}

Table 6 shows the comparison of the combined mean effect sizes for all variables, namely maternal knowledge and family support. The average value of the largest effect size is 0.4205 (medium effect) on the mother's knowledge variable, while the family support variable has a smaller average effect size of 0.40 (medium effect).

\section{DISCUSSION}

The relationship of knowledge with the behavior of mothers of children under five in the use of posyandu

In the results of a study of 9 articles related to knowledge with the behavior of mothers of children under five in the use of posyandu, it can be seen that the highest p-OR number is in the research of Reihanah et.al, (2016) which is 4.614. This means that mothers with high knowledge have a tendency of 4.614 times to posyandu than mothers with low knowledge. While the lowest p-OR value is found in Yanti M et.al's research (2018), which is 1.857 , which means that mothers with high knowledge have a tendency of 1.857 times to go to posyandu than mothers with low knowledge. After merging in the meta-analysis test, the results obtained $\mathrm{p}$ value $<0.0001$ and a pooled odds ratio value of 2.91 (95\% CI2.36-3.61), which shows that there is a relationship between knowledge and behavior of mothers of children under five in the use of posyandu.

According to Reihanah et al., (2016) Posyandu programs will be beneficial if toddlers visit the posyandu regularly. The regularity of toddlers visiting the posyandu really depends on the mother's participation in bringing her toddler to visit the posyandu. This is in line with Gusmayesy Y (2017) the relationship between mother's knowledge about Posyandu and toddler visits to Posyandu because mother's knowledge and awareness about maintaining and improving health is the beginning of health empowerment. The cause of poor mother visits to Posyandu is due to the lack of information obtained, and limited knowledge is due to the fact that mothers generally graduate from elementary and junior high schools so that mothers still find it difficult to receive knowledge or insight to improve the health status of their children. Knowledge is the initial stage of the emergence of abilities, because knowledge is the result of the learning process. Therefore, being able to maintain and improve health by bringing toddlers to the Posyandu is also a health learning process that begins with obtaining information about health. Health information raises awareness of the mother and the result is mother's knowledge about the health of her toddler. And Yanti M et.al (2018) assumes that with good knowledge that mothers of toddlers have about posyandu, there is a tendency to influence the formation of behavior, namely mothers of toddlers can actively participate in posyandu. If the behavior is not based on knowledge, it will be difficult to maintain its sustainability, and vice versa if the behavior is based on knowledge, then the behavior will be lasting.

The researcher considered that the inconsistent results of the relationship between knowledge and mother's behavior in the use of posyandu apart from the weight and strength of the research which were not ideal, were also related to differences in place and socio-culture, where people living in rural areas had a lower tendency to visit and weighing their children at posyandu compared to urban areas.

According to the researcher's assessment, mothers who have low knowledge about basic health, maternal and child health, and about posyandu activities do not understand the importance of posyandu, so that it will have an impact on mother's behavior in using posyandu. Knowing the importance of posyandu and the benefits derived from posyandu activities will certainly change mothers' thoughts and behavior towards the use of posyandu.

\section{The relationship of knowledge with mothers of children} under five in the use of posyandu

In the results of a study of 8 articles related to family support with the behavior of mothers of children under five in the use of posyandu, it can be seen that the highest p-OR rate was in Ernawati et.al's (2016) study, which was 7.51. This means that mothers who get family support have a tendency of 7.51 times to go to posyandu than mothers who do not get family support. While the lowest p-OR value and which states that there is no relationship between family support and maternal behavior in the use of posyandu are found in the research of Widiyanto et.al (2020) which is 0.96 , which means that mothers who receive family support have a tendency of 0.96 times to go to posyandu. than mothers with no family support. After merging in the metaanalysis test, the results obtained $\mathrm{p}$ value $<0.0001$ and the pooled odds ratio value of 2.76 (95\% CI 2.18-3.51), 
According to the assumption, Yanti M et.al (2018) stated that the low coverage of weighing toddlers to the Posyandu at the Padang City Health Center was due to family support factors. Therefore, there is a relationship between family support and the coverage of weighing children under five to the Posyandu. Mothers of toddlers who get good support from their families generally still have a high coverage of toddler weighing, this is probably because family support always reminds Posyandu schedules and provides encouragement to bring their toddlers to Posyandu. Meanwhile, mothers of toddlers who have poor family support, do not have a high coverage of weighing toddlers, possibly due to the absence of family members who replace mothers to bring their toddlers to the Posyandu when the mother works.

However, the research by Widiyanto et al (2020) stated that there was no family support with the mother's interest in visiting the posyandu with a p-value $>0.05$, namely 0.945 with OR 0.959 and CI: $0.289-3.187$. This shows that support from the family does not affect the mother's interest in going to the posyandu.

According to Widiyanto et al (2020) the relationship of family support does not affect or has nothing to do with the mother's interest in visiting the posyandu because mothers who are concerned with the health and development of their toddlers do not need family support because mothers have their own desire to bring their toddlers to visit the posyandu.

According to researchers, family support is one of the driving factors in maternal behavior in the use of posyandu. With the support of the family can improve the behavior of mothers in the use of posyandu.

\section{Large comparison of the strength of the relationship between variables}

Based on the results of the meta-analysis, it is known that the two variables in the study, namely knowledge and family support, both have a statistical relationship with the behavior of mothers in using posyandu. Based on the results of the metaanalysis, it can also be seen that the knowledge variable has a stronger relationship than the family support variable. This can be seen from the combined $\mathrm{z}$-value, the $\mathrm{z}$-value on the knowledge variable is 9.84 and the family support variable is 8.35. In addition, the pOR value on the knowledge variable is also greater than family support. The pOR value on the knowledge variable is 2.91 , meaning that mothers who have high knowledge have a tendency to increase the risk of 2, 91 times the behavior of mothers under five in the use of posyandu compared to mothers who have low knowledge. As for the family support variable, the pOR value is 2.76 , meaning that mothers who receive family support have a tendency to increase the risk of 2.76 times the behavior of mothers under five in the use of posyandu compared to mothers who do not receive family support.

From the results of the study, it can be concluded that respondents who have high knowledge are more likely to participate in visits to posyandu, because they understand the importance of posyandu for the health of their toddlers. Knowledge is very important to change and shape one's behavior, with high knowledge a person will quickly adopt new behaviors that are good for himself and others.

This publication is licensed under Creative Commons Attribution CC BY.

http://dx.doi.org/10.29322/IJSRP.11.07.2021.p11525
This is in line with Idaningsih A's research (2016), the results of multivariate analysis showed that the OR value for the setting variable was greater than the OR value for the family support variable, where the OR value for the knowledge variable was 3.176 and the OR value for the family support variable was 3.176. 2,159. This means that maternal knowledge can increase the behavior of mothers under five in the use of posyandu by 3,176 times, and family support can increase the behavior of mothers in using posyandu by 2,159 times.

According to Roger in Notoatmodjo (2010) that behavior that is based on knowledge will be more lasting than one that is not based on knowledge. Based on the theory of Lawrence Green in 1980 in Notoatmodjo, it has been explained that increased knowledge is not always the cause of a person's behavior change, but is closely related to a person's initial determinants of behavior.

According to research by Djamil A (2017), the reinforcing factor for someone to behave in a healthy manner is based on family support. Mother will be active in Posyandu if there is encouragement from the closest people, including family. The family is the basic system in which healthy behavior and health care are regulated, carried out, and secured. The family provides preventive health care and jointly cares for family members. The family has the primary responsibility for initiating and coordinating the services provided by health workers.

\section{CONCLUSION}

Based on the results of meta-analysis and data synthesis from previous research articles that match the inclusion criteria, it can be concluded that:

1. In the mother's knowledge variable, it was found that there was a relationship between mother's knowledge and mother's visit to the posyandu had a moderate effect, where mothers who had high knowledge increased the risk or tended to be 2.91 times to carry out the behavior of mothers of toddlers in the use of posyandu compared to mothers who had high levels of knowledge low.

2. In the family support variable, the results showed that there was a relationship between family support and the behavior of mothers under five in the use of posyandu which had a low effect, where mothers who received family support increased the risk or had a tendency of 2.76 times to perform the behavior of mothers under five in the use of posyandu compared to mothers who did not. get family support.

3. Of the two variables studied, the mother's knowledge variable has a stronger effect than the family support variable.

\section{REFERENCES}

Amalia, E., Syahrida, Andriani, Y. (2019) Faktor Mempengaruhi Kunjungan Ibu Membawa Balita ke Posyandu Kelurahan Tanjung Pauh Tahun 2018. Jurnal Kesehatan Perintis (Perintis's Health Journal) Vol. 6 No. 1; 60-67.

Anwar, R. (2005) Meta Analisis. Subbagian Fertilitas dan Endokrinologi Reproduksi Bagian Obstetri dan Ginekologi Fakultas Kedokteran UNPAD. Bandung. 
ISSN 2250-3153

Djamil, A. (2017) Faktor-faktor yang berhubungan dengan Perilaku Ibu Balita Menimbang Anaknya ke Posyandu. Jurnal Kesehatan Volume VIII, Nomor 1; 127-134.

Fauziah, Mardjan, Hernawan A.D. (2015) Hubungan antara Faktor Reinforcing dan Aksesabilitas Posyandu dengan Kunjungan Ibu Membawa Anak Balita ke Posyandu di Desa Rasau Jaya1. JUMANTIK Jurnal Mahasiswa dan Peneliti Kesehatan Vol. 1 No. 1; 38-49.

Gumayesty, Y. (2017) Determinan Kunjungan Anak Bawah Lima Tahun ke Posyandu di Kelurahan Pusaran Kecamatan Enok Kabupaten Indragiri Hilir. Jurnal Kesehatan Komunitas Volume 3 Nomor 4; 138-144.

Harahap SA, Silaban Gerry, Lubis FH. (2020) Faktor Yang Berhubungan Dengan Keaktifan Kunjungan Ibu Balita Usia 24-60 Bulan Ke Posyandu Di Desa Sialagundi Kecamatan Sipirok Kabupaten Tapanuli Selatan Tahun 2020. Jurnal Inovasi Kesehatan Masyarakat Vol. 02 Nomor 02.

Idaningsih, A. (2016) Faktor-faktor yang berhubungan dengan Kunjungan Balita ke Posyandu. Jurnal Ilmiah Indonesia Vol. 1 No. 2; 16-29.

Ifroh RH, Susanti R, Winanda W. (2018). Kajian Teori Who Mengenai Jumlah Kunjungan Ibu Ke Posyandu Tarap Guna Meningkatkan Cakupan D/S Bayi-Balita. Preventif: Jurnal Kesehatan Masyarakat Volume 9 Nomor 1.

Kemenkes RI. 2011. Panduan Penyelenggaraan Pemberian Makanan Tambahan Pemulihan Bagi Balita Gizi Kurang. Bantuan Operasional Kesehatan. Jakarta: Ditjend Bina Gizi dan KIA.

Kementerian Kesehatan Republik Indonesia. (2013) Buku Saku Posyandu. Penerbit: Pusat Promosi Kesehatan Kemenkes RI. Jakarta.
Notoatmojo, S. (2007). Promosi Kesehatan dan Ilmu Perilaku. Jakarta :Rineka Cipta.

Notoatmojo, S. (2010). Ilmu Perilaku Kesehatan. Jakarta :Rineka Cipta.

Reihana, Duarsa, A.B.D. (2016) Faktor-faktor yang berhubungan dengan Tingkat Partisipasi Ibu Balita untuk Menimbang Balita ke Posyandu di Wilayah Kerja Puskesmas Panjang Bandar Lampung tahun 2010. Jurnal Kebijakan Kesehatan Indonesia Vol. 05 No. 2; 67-72.

Setiati NW, Rosdiana Nina, Hermawanti ID. (2019) Hubungan Tingkat Pengetahuan Ibu Tentang Posyandu Yang Memiliki Balita Dengan Kunjungan Posyandu Di Desa Payung Agung Kecamatan Panumbangan Kabupaten Ciamis. Jurnal Kesehatan Bakti Tunas Husada: Jurnal Ilmu Ilmu Keperawatan, Analis Kesehatan dan Farmasi Volume 19 Nomor 2.

Sumini. (2014). Hubungan Motivasi Dengan Keaktifan Ibu Membawa Balita Ke Posyandu Di Kelurahan Tonatan Kecamatan Ponorogo Kabupaten Ponorogo. Jurnal Delima Harapan, 3(2), 38-46.

Widiyanto J, Zebura S. (2018). Faktor Eksternal Yang Berhubungan Dengan Minat Ibu Melakukan Kunjungan Ke Posyandu (Studi Di Kelurahan Labuh Baru Timur). Jurnal Sains dan Kesehatan Vol 11 No. 1.

Yanti. M., Asbiran. N., Rusti. S. (2019) Analisis Faktor yang Mempengaruhi Cakupan Penimbangan Balita ke Posyandu di Kota Padang tahun 2018. JIK (Jurnal Ilmu Kesehatan) Volume 3 No.1.

Yuniyanti, Bekti. (2016). "Asuhan Kebidanan Komunitas". Trans medika. Yogyakarta. 